\title{
Oke-Ibadan Festival and the Ethnography of Aboke people of Ibadan
}

\author{
Oludele Mayowa Solaja and Adesina Abass Olayiwola \\ Olabisi Onabanjo University, Ago-Iwoye, Nigeria \\ postgraduatescholar@gmail.com
}

\begin{abstract}
This study examines Oke-Ibadan festival and the ethnography of Aboke people of Ibadan. The objectives of the study are to document the cultural identity, fashion, family life-style, crafts, and hobbies of Aboke people; and, also, ascertain the significance of Oke-Ibadan festival to Aboke's at home and abroad. Two sociological perspectives which include structural-functionalism and symbolic interactionism were used to provide a theoretical context for the study. The study adopts exploratory survey design which includes purposive and convenience sampling techniques. Thirty-five (35) participants were selected for the study. The instruments used in eliciting information from the participants were in-depth interview (IDI) guide and focus group discussion (FGD) guide, while the responses were gathered with the aid of electronic gadget such as the audio recorder. The data were analyzed using descriptive statistics, content analysis, and ethnography summary. The finding revealed that Aboke people have a unique cultural identity among other ethnic groups in Yorubaland. Their cultural identity as attested to by the participants include; hosting of Oke-Ibadan festival, retaining tribal mark, production of traditional/black soap for the cure of measles, narrating folk stories to the young generation in order to encourage high fertility rate, unique dress code, and acceptable physical appearance.
\end{abstract}

\section{Introduction}

Culture is the most critical point of reference in human existence. It is practically impossible to refer to a group of people validly except within the framework of culture. This is essentially so because people are the culture and culture is the people (Akanle and Olutayo 2012). In a lay man's language, culture can be defined as the way of life of people in totality. It entails both 
material and non-material components of human cultural heritage. As an element of cultural heritage, festival is an event organized by people of a particular community or ethnic group to celebrate their belief, tradition, ancestor, and cultural prowess. In Africa, festival is one of the efforts made by individuals and group of people to maintain a significant feature of their socio-cultural heritage (Asogwa, Umeh and Okwoche 2012). It is a periodic event of merry-making set aside by members of a community for the observance of sacred celebration, religious, solemnities, musical and traditional performance of social significance (Asogwa, Umeh and Okwoche 2012). Thus, festivals are the manifestation of culture in Africa traditional society (Ezenagu and Olatunji 2014). In light of this, this essay examines the Oke-Ibadan festival and the ethnography of the Aboke people of Ibadan.

Oke-Ibadan festival is among the unique festivals in Yorubaland. It is organized on annual basis to reiterate the basic values, beliefs, traditions, religion and cultural distinctiveness of the Aboke people of Ibadan. Just like other festivals in Yorubaland, Oke-Ibadan festival displays unique aspects of Aboke community through a set of activities and practices designed to entertain, educate, castigate improper behavior, and promote unity among the people of Aboke community. The festival is probably the oldest among its kind in Yorubaland.

Due to the significance of Oke-Ibadan festival, a large crowd of people participate in the festivities. Important to note is that Oke-Ibadan festival is non-fetish or religious, but a socio-cultural and tourism event organized in the month of March every year. Apart from symbolizing the general cultural heritage and history of Ibadan, the festival serves a considerable amount of sociological and psychological satisfaction to the people of Ibadan and its diaspora. There is the urgent need to document the cultural identity, fashion, family life style, crafts and hobbies of Aboke people. This academic assignment is important, particularly in the era of superficial claims that technological advancement and globalization had altered the socio-cultural beliefs of African people and that African culture had been subdue by a foreign culture. Corroborating this view, Amadi and Agena, (2015) claimed that technological advancement and globalization had caused culture mutation among the Igbo people of the eastern part of Nigeria which resulted in the creation of new mode of behavior, life style, and identity. This disposition to an extent may be true among the Yoruba where the constant shift away from the practice of indigenous religion has given way to the increasing rate in the practice of Christianity and Islam. However, festivals such as Egungun, Agemo, Eyo, Oke-Ibadan among others are still being observed with a high sense of belonging. 
Therefore, it is important to reconfigure the various misunderstanding and misinterpretations emanating from skewed ideology of the impact of globalization and technological advancement on contemporary African cultural heritage. To this end, some scholars who are concerned about the reality and potency of Africa's cultural heritage in today's modern world have reported that African traditions and customs are being overshadowed by the light of westernization and globalization (Adekola 2014, Ajayi 2009, and Adekola and Alamu 1991). Therefore, it is often noted that socio-cultural belief and tradition of African people which could have been the catalyst to African development have been rendered insignificant, irrelevant, and pseudo-scientific (Adekola, 2014). This disposition, however, is not a hundred percent correct. This is the reason why it is important to understand the importance of OkeIbadan festival and the ethnography of the Aboke people of Ibadan. In this regard, this essay shall discuss the significance of celebrating the Oke-Ibadan festival annually. The essay shall provide insight into how Aboke people utilize popular local black soap to cure measles and malaria. In addition, the essay will reveal how Aboke people perform the Oke-Ibadan festival rituals through the directives of Ifa, the god of divinity.

\section{Study Location}

This study was conducted in Aboke compound at Bere, which happens to be a popular and ancient area in Ibadan North East Local Government Area, Oyo State. The population of the study made up of sons and daughters of Aboke compound who work and reside in Aboke community. The sample size of the study was drawn among the elders of this group using a purposive sampling method. Therefore, the sample size of this study includes the male and female elders of Aboke compound who are knowledgeable about the historical antecedents of the group. In order to get information about the study, the purposive sampling techniques were employed as it allowed the researchers to get information from the people who know the history of the group. Also, the purposive sampling technique was instrumental in terms of time, convenience, and economic resources available. The respondents include The Aboke of Ibadan land - Chief Ifasola Ifamapowa, Mr Ismaila Aboke Aderibigbe, Chief Adex Fakayode, Mr Musiliu Aboke, Mr Kamilu Raheem Aboke, and Mr Adetunji Kazzim Aboke.

This study made use of primary data; information was gathered directly from the respondents/hosts using different forms of primary data collection techniques such as Focus Group Discussion, In-depth interview, Key Informant and Personal experience of the researcher. This was done successfully with the aids of electronic devices such as video and tape recorder. 
Furthermore, the information gathered in the cause of this study was analyzed using descriptive statistics, content analysis and ethnographic summaries. The socio-demographic variables of participants were presented in the table using frequency distribution and percentages. For qualitative data, raw data from in-depth interviews were transcribed, sorted, and labelled. However, verbatim quotations, ethnographic summaries and content analysis were used for analysis and also to highlight the subject matter under discussion.

\section{Data Presentation and Analysis: Demographic Characteristics of Participants}

The significance of analyzing demographic data in any research study is to reveal the population characteristics in terms of sex, age, religion, occupation etc. These factors can also be used to differentiate the respondents from one another. More so, analyzing demographic characteristics of respondent can serve as a useful parameter to compare respondents' opinion with each other. This lies in the fact that the responses to substantive research issues by respondents tend to be influenced by their socio-economic status. In this light, the following presentation depicts the demographic characteristics of the research respondents in the study areas. As noted earlier, this study selected twenty-five (25) respondents for in-depth interviews and ten (10) participants took part in the Focus Group Discussion. Table 1 below revealed the distribution of the respondents along with socio-demographic variables such as sex, age, occupation, religion and the likes.

\begin{tabular}{|l|l|l|l|}
\hline Variables & IDIs Participants & FGD Participants & Total (\%) \\
\hline Sex & 25 & 07 & $32(91.4)$ \\
Male & - & 03 & $03(8.6)$ \\
Female & & & $35(100.0)$ \\
\hline Age & & 2 & \\
$28-37$ & 08 & 6 & $10(28.6)$ \\
$38-47$ & 11 & 2 & $17(48.5)$ \\
$48 y r s$ and above & 06 & & $08(22.9)$ \\
Total & & - & $35(100.0)$ \\
\hline Occupation & & 07 & $06(17.1)$ \\
Artisans & 06 & 03 & $10(28.6)$ \\
Traders & 03 & & $19(54.3)$ \\
Drivers & 16 & & $35(100.0)$ \\
& & &
\end{tabular}




\begin{tabular}{|l|l|l|l|}
\hline Religion & & & $13(37.1)$ \\
Traditional & 09 & 04 & $17(48.6)$ \\
Muslim & 11 & 06 & $05(14.3)$ \\
Christian & 05 & - & $35(100.0)$ \\
& & & \\
\hline
\end{tabular}

Table 1: Showing the Demographic Characteristics of the Respondents

(Source: Field Survey, 2014)

Results of socio-economic and demographic characteristics of the respondents as presented in Table 1 showed that 32 participants representing 91.4\% were male participants; while 3 participants representing $8.6 \%$ were female. It shows that there are more male than female counterpart in the study. The reason for this is based on the fact that women are often restricted from participating in activities relating to the festival and its rituals. Also, for the majority of the respondents' (48.5\%) their age bracket fell between 38-47, while the least (22.9\%) fell within 48 and above. The occupational distribution shows that majority (54.3\%) of the participants are commercial drivers followed by $28.6 \%$ who are traders, and the least (17.1\%) who are artisans. Hence, all the participants engage in one form of economic activity or the other to earn a living. Moreover, the religious affiliation of the respondents showed that Christians constituted 14.3\%, Muslims constituted 48.6\%, while Traditional worshippers constituted only $37.1 \%$. The result shows that Aboke people of Ibadan are multi-religious despite their commitment to their traditional rights.

\section{Major Findings}

The response of respondents in accordance to the stated research questions are presented below using content analysis and ethnographic summaries to ascertain the opinion of respondents on each research question asked.

\section{The Unique Cultural Heritage of Aboke People}

Basically, cultural heritage connotes the legacy of physical artefacts and intangible attributes of a group or society that are inherited from past generations, maintain in the present and bestowed for the future generations. Cultural heritage encompasses tangible culture (i.e. building, landscapes, books, works of art and artefacts), intangible culture (i.e. folklore, traditions, language and knowledge) and natural heritage (i.e. cultural significant and biodiversity). Cultural heritage is unique and irreplaceable, and it places responsibility of preservation on the current generation. To achieve this aim questions were asked on what are the cultural heritage of Aboke people of Ibadan among the respondents and their responses were recorded. Encapsulating the cultural heritage of Aboke people, a male respondent said: 
One of the noticeable features that distinguished Aboke people from other tribe, in Ibadan land is their unique tribal mark which is called pele in the Yoruba language... This tribal mark appears in form of three upright marks on both side of their face. (IDI/Male/ Resident/Aboke Compound/2014)

Investigating the issue further, a 38-year old male respondent revealed that:

Aboke people are the generation of Lagelu, the first person to discover Ibadan. Lagelu was among the warriors that were displaced by wars that occurred in Ile-Ife and later found refuge with the spirit of the hill in a place known today as Oke-Ibadan... Aboke people are known by their way of pronunciation, folklore, names and way of life. For instance, oka (a meal made from yam flour) is known as amala among the Aboke people; this is different from the way it is called by another tribe in Ibadan. Also, hawking of yam or even pounded yam is not allowed within Aboke compound, Aboke people are expected to eat pounded yam once in a year mostly during Oke-Ibadan festival. (IDI/Male/ Resident/Aboke Compound/2014).

To buttress the foregoing discourse, a male respondent was very emphatic when he said:

Aboke people are predominantly traditional worshipers in spite of the civilization that has ushered in other religions like Islam and Christianity into Nigerian society today... Of course, some Aboke people practice other religion however; the oath that has been taken by our forefathers still restrains them to traditional worshiping... Part of the features of Aboke people is their dress code/ hair style during Aboke festival. The head of the Aboke people usually dressed in female dress code with his hair plaited in traditional female hair style at all times. While others are allowed to wear their shoes, the head of Aboke walked with bare legs during and after the festival (IDI/Male/Resident/Aboke Compound/2014).

When we asked why the head of Aboke walks without wearing his shoes, He said:

The head of the Aboke walks with his bare legs and kept his hair platted like that of a female because it is the tradition of the Aboke people. The tradition started from our forefathers who seek powers from the spirit of Aboke, a female goddess and vowed to imitate her appearance at all times. (IDI/Male/Resident/Aboke Compound/2014). 
To corroborate the responses given by the respondents, the head of Aboke compound was interviewed, and he affirmed that:

Aboke's are those who first settled in Ibadan and we are the true sons and daughters of Ibadan. Oke-Ibadan festival that we celebrate every year is to commemorate our ancestors and forefathers who fought for peace, protection and progress in Ibadan. In their quest for peace, protection and progress they consulted the spirit of the hills in Ibadan who assured them of their aspirations. In return, the Aboke's vowed to always worship the spirit at the starting of a new farming season that is why we celebrate Aboke festival in March of every year... Abokes have a unique cultural heritage. Our tribal mark is different from that of other indigenes of Ibadan, with it alone we are recognized anywhere we go. More so, our traditional healing soap is second to none; this soap cures measles and other skin diseases hence; people all over Nigeria and outside the country come to buy it from us here. Consequently, people come from far and near to Oke-Ibadan festival to watch our unique traditions and culture; as you can see, I am dressed in female dress code (wearing head gear or gele in Yoruba) and I am walking with no shoes on my legs. (IDI/Male/Head/Aboke Compound/2014).

From the above responses, it could be inferred that the unique cultural heritage of Aboke people as envisage by the respondents include; the famous Oke-Ibadan festival, tribal mark, traditional healing soap, unique dress code and appearance etc. These cultural heritages make Aboke people popular and distinct from the other tribe in Ibadan and Yoruba Land in general.

\section{The Significance of Oke-Ibadan Festival}

Festival is an event or period of celebration marked by feasting; ceremonies or other observances associated with a group of people. When asked to comment on the significance of Oke-Ibadan festival, an elderly man of about 89 -years old during an interview stated that:

The Okebadan festival is an occasion of universal rejoicing and merriment for the whole of Ibadan. It is the reenactment of Ibadan socio-cultural traditions and should not be forgotten if our offspring are not to be misinformed. (IDI/Male/Resident/Aboke Compound/2014.

In corroborating the statement above, a female leader gives an oral revelation during the FGD when she affirmed that: 
Oke Ibadan is an annual event that paves way for peace and smooth organization of Ibadanland. During the festival, the Aboke prays for the Olubadan and his chiefs. Any chief who the Aboke fails to visit his/her residence has to be very careful, for this is an indirect way of telling such a chief to improve upon his or her behavior in the society. The festival also brings peace and harmony to the inhabitants and sets the pace for a reunion among the people who participate in the festival. Significantly, the festival is believed to increase the number of children in the town and pave a way for a bumper harvest. (IDI/Male/Resident/Aboke Compound/2014).

Another interviewee stated that:

Oke-badan festival is celebrated to foster peace, improve sanitation and cooperation among the people. More so, vulgar songs are sung during the festival to educate the younger generation of their tradition and to sensitize them against immoral acts and utterances. (IDI/Male/Resident/Aboke Compound/2014).

With reference to the so called obscene or vulgar songs sang during the Okebadan festival, Head of Aboke compound said:

Oke-Ibadan festival is not celebrated for fun. It is specifically carried out to educate the younger ones about the significance of the festival. And to enlighten those who are ignorant of their origin... The day is usually attended with simulated moral laxity and excesses, singing Oke-Ibadan festival songs. This should not be perceived as immoral acts and utterances. Perhaps, it is true that promiscuity may have been practiced and engaged in during the period being reenacted, but such is now only a symbolic ritual commonly featured in Oke-Ibadan festival and many other festivals like it, connected with fertility cults. Thus, this event is to remind all and sundry of the people's historical past. (IDI/Male/Head/Aboke Compound/2014)

The deductions that may be drawn from the above views are that OkeIbadan festival is celebrated to give thanks to the Almighty God (Olodumare) for His protection and for saving the town from extinction. The celebration also serves as a commemorative occasion for the descendants of the past heroes and the founding fathers of the city (Ibadan) that had done a lot to establish the historic city, which, within a very short time has become renowned. Additionally, Oke Ibadan festival is believed to facilitate fertility for barren women who participate in the festival and it is also an occasion to honor the founders of Ibadan and the goddess of the hill. 


\section{The Ritual Point and Activities During the Festival}

Many rituals and festivals take place in public, meaning that such expressions of faith are societal as well as individual. It is important to note that these are not simply empty shows but they have a significant meaning for the benefit of the participant as well as viewers. However, the objective here is to document the ritual point and activities during Oke-Ibadan festival. To achieve this objective, an ethnographic summary of ritual point and activities during Oke-Ibadan festival in March 2014 is presented below:

As earlier stated Oke-Ibadan is one of the festivals celebrated annually in Ibadan. The Oke-Ibadan festival is usually accompanied with pomp and pageantry and the materials to be used for the celebration are usually provided by the paramount ruler the Olubadan - fish, snails, tortoise, dogs, etc. (Saka Aleshinloye, Oral Comm. 2001). Nobody was allowed to go to the farm on that day and the people would take hot pap in the morning in remembrance of the critical period when Lagelu and his subjects ate only fruits of oro, snails and hot pap in snail shells.

Furthermore, rituals are performed by the Aboke at the Oke-Ibadan shrine. The Aboke though a man, dressed like a woman on the Oke-Ibadan day, with his hair plaited and braided like that of a woman. He ties wrapper around his waist to show the traditional belief that the spirit inhabiting the hill is a woman. The tradition persists in saying that Oke-Ibadan is a goddess with immense breasts. This is probably why the Oke-Ibadan deity is usually given the praise name àtàgé ọlọmú orù (high deified hill goddess who possessed large breasts). After the ritual performance, the people start going about on the streets of Ibadan showing their enthusiasm, love and solidarity for the festival and the Aboke. During the one day celebration, various kinds of songs are sung by the Aboke and the adherents of Oke-Ibadan. Although some of these songs may look irrational, embarrassing, unethical, etc., to strangers, they are songs that portray historical facts and are means of re-enacting what happened during the early days of Ibadan. Majority of the songs point to the period in Lagelu's time when people moved about half naked. Some songs are reminders to Ibadan war activities and their encounters with neighboring towns and villages. Meanwhile, it is pertinent to produce some of the OkeIbadan songs here. These are:

1.

Bàbá tó ń lọ

Jàwàjawa ẹpọn

$\mathrm{Hi}$, old man going

You are with a dangling scrotum 
2.

Okóo tísà

Òbòo mísísi

Okóo tísà

Kikii sọọki

Teacher's penis

Mistress vagina

Teacher's penis

Tainted with chalk

3.

Okó ọlọpàá

Kikii bẹlíti

Police man's penis

As big as his belt

4.

Ờré mẹta

Jàwàjawa ẹpọn

E máa bú mi

Jàwàjawa ẹpọn

Three friends

You are with a dangling scrotum

Continue to abuse me

With your dangling scrotums

5.

E bá mi gbọ́lọ

Emi ó pa kórópọn

Bring me a grinding stone

I will break the scrotum

6.

Aláboyún, òbò re gba líifu

Fọ́dún mẹta, òbò re gba líifù

Hi! Pregnant woman, your vagina is on leave

For three years, your vagina is on leave

7.

Mo gbọ́ kereú

Eegun òbò lajá ń jẹ

I heard a cracking sound 
Alas! It is the vagina's bone the dog is eating

8.

Onikẹkẹ

Rọra wàkè

Okó ń le

The bicycle rider

Ascend the hill cautiously

For, your penis is erecting

9.

Okó onímọtò

Bí irèké

İyàwó onímọtò

Kú irọjú

The motor driver's penis

Is like the sugar cane

The wife of the driver

Should be commended for her endurance

10.

Ponikiti lokoo le

Mee bòbò

Òbò Òsú mee bơ

Òbò Òsú mee bọ

The penis erects rigidly

I'll insert it into the vagina

Into the vagina of the Osu woman

Into the vagina of the Osu woman

The above songs have their historical and socio-cultural meanings. While some try to stimulate sexual action at the period, some point to historical past and what happened one time or the other. As already discussed above, at the time there was pandemonium within the Ibadan enclave, many of those songs were rendered and sung by the people through the instruction of the oracle. During this period, due to panic, many children died prematurely while some pregnant women even died during labor. Some of these songs are also used to scare away obstinate traders who intended to display their wares in market place on Oke-Ibadan festival day.

Moreover, the reason why Oke-Ibadan festival is being celebrated by the middle of March annually has been highlighted above. In a nutshell, it is 
to commemorate the events that led to the derivation of this nomenclature and to pin-point the protection and assistance which their forebears received from the tutelary deity of the hill at the period when this town was being established.

\section{Ethnography of Aboke People in Terms of Religion, Language, Fashions, Family Life, Crafts and Hobbies}

Globally, religious beliefs and customs/tradition are interwoven. Individuals in a community may belong to distinctive religious groups which follow different doctrines, yet the whole community usually comes together in matters that concern their common heritage and customary beliefs. Therefore, traditional festivals are usually embraced by all and sundry without minding one's religious leaning. In this case, a particular religion may be a concern of a few people but customs and tradition connect every indigene of the community. Religion may require it will be adherents to get initiated before becoming a full-fledged member of a particular sect (be it orthodox or indigenous faith) but participation in a cultural or traditional reenactment of events does not require any initiation ceremony or ritual. Based on this reality, the objective of this study is to examine Aboke people in terms of religion, language, fashions, family life, crafts and hobbies. Thus, the response generated from the respondents during the IDIs and FGD were presented as follows:

An interviewee said:

It is true that tradition, religion and custom intersect among one another; they differ faintly in some respects... The customary beliefs of a group of people may connote the peculiar behavior and practices of such community. For instance, it's prohibited in Aboke compound to sell yam or eat pounded yam except during Oke-Ibadan festival. Also, among the Ijebu's (another fraction of Yoruba people who settled in Ogun State), there are Oro and Agemo festivals which are some of their traditions that they carried out to appease the gods and prohibits immoral acts or crime. Thus, there is no community in the world without her own unique traditional beliefs, practices and festivities. Therefore, Oke-Ibadan festival and ritual activities are commemorated annually or periodically to remind the people and their offspring of the significance of their traditions regardless of one religion. (IDI/Male/Head/Aboke Compound/2014)

Another interviewee affirmed:

The Aboke people speak the normal Yoruba Language which originated from Ile-Ife. As such, the way marriage ceremony is conducted among 
Yoruba people is the same way we (Aboke people) carry out marriage rite. Our children are allowed to bring home whosoever they are in love with and willing to marry as wife. Parents are just to support the children in prayers and finance to ensure that the union is sustainable. As regard Aboke religion, we practice all the three (3) major religions in Yorubaland; there are Islam, Christianity and indigenous religion. And we all celebrate the Oke-Ibadan festival annually... Our religion did not separate us from observing our traditions and cultural heritage. (IDI/Male/Head/ Aboke Compound/2014)

As regards the fashion, family life, craft and hobbies of Aboke people, a male respondent explicated that:

Our dress code is the same with the normal Ibadan-Yoruba dress code. We wear traditional attires like the òfi, aṣo òkè, àdire gbáríyẹ, òyàlà and dànșíki as well as contemporary mode of dressing however; this is common among our youths. We live in an extended and nuclear family setting. Though, our matured sons and daughters do migrate as a result of marriage or economic activities... Our craft includes; blacksmithing, pottery, cloth weaving, and local soap making etc. while our hobbies are driving, traveling, celebrating Aboke festival etc.

From the responses above it is obvious that in this current dispensation, where societal or current values and practices are deteriorating as a result of westernization, globalization, information and communication technology and other means or tools of socio-cultural change, the socio-cultural beliefs of our environment had been negatively affected by the various misunderstanding and misinterpretations emanating from ill-conceived notions of various individual and religious groups. The Aboke people of Ibadan still protect and promote their cultural heritage and traditions through the celebration of OkeIbadan festivals and ritual activities carried out during the festival. The further observation here is that traditional festivals are usually embraced by all and sundry without minding ones' religious leaning. In this case, a particular religion may be a concern of a few people but customs or tradition connects every indigene of the community.

\section{Summary and Conclusion}

From the discussion so far, it can be inferred that the Aboke people of Ibadan are gifted with rich and unique traditions and cultural heritage among other social groups in Ibadan. The Aboke people through their strong beliefs and willingness to protect their cultural heritage come together annually to 
celebrate Oke-Ibadan festival. Oke-Ibadan festival is an occasion of universal rejoicing and merriment among the Aboke people and the whole of Ibadan. It is celebrated to give thanks to the Almighty God for His protection and for saving the town from extinction. The celebration also serves as a commemorative occasion for the descendants of the past heroes and founding fathers of the city.

In addition, Oke-Ibadan festival can be referred to Ibadan founders' Day celebration. Despite the fact that some people, due to their narrow religious views see the celebration as fetish, and barbaric, it is hereby submitted that the celebration of Oke-Ibadan festival is an observation of important custom/ tradition of the Aboke people. It used to be a period of the complete holiday when work and trade in the market were forbidden. Finally, it should be realized that religions and custom/tradition usually intermingle with one another. However, while religion focuses mainly on the worship of a particular deity, custom deal with traditional acts, practices or commemoration of a historical event.

\section{Bibliography}

Amadi, L. and Agena, E. J. (2015). "Globalization, culture mutation and new identity: Implications for the Igbo cultural heritage." African Journal of History and Culture. Vol. 7 (1) pp:16-27

Adekola, O. A. (1991). "Okebadan" Discussion on the Significance of Okebadan Festival in contemporary period at a symposium organized by the Okebadan Union on $17^{\text {th }}$ March, 1988 at Mapo Hall, Ibadan.

Akinyele, I. B. (1950). Iwe Itan Ibadan Ati die Ninu Awon Agbegbe Re bi Iwo, Oshogbo Ati Ikirun. Exeter: James Townsend (1981 edition).

Ajayi, A.T. (2009). "The Preservation and Conservation of Nigerian Cultural Heritage: An Impetus for Her Development." Medwell Journal of the Socal Sciences. Vol. 4 (5):407-410

Akanle, O. and A. O. Olutayo, (2012). "Ethnography of Kinship Constructions Among International Returnees inn Nigeria: Proverbs as The Horses Of Words." Journal of Anthropological Research. Vol. 68, No. 2: 249-271

Asogwa, C.B. C. J. Umeh, and A.V. Okwoche. (2012). "The Sociological and Cultural Significance of the Argungu International Fishing and Cultural Festival in Nigeria." International Journal of Humanities and Social Science. Vol. 2 No. 11: 243-249

Ekpenyong, G. (1981). Festivals in Nigeria. A Bibliography Nigeria magazine Lagos: Emmacon Print Ltd. 
Ezenagu, N. and T. Olatunju. (2014). "Harnessing Awka Traditional Festival For Tourism Promotion." Global Journal of Arts Humanities and Social Sciences Vol.2, No.5: 43-56

Merton, R. (1957). Social Theory and Social Structure. New York: Free Press. 